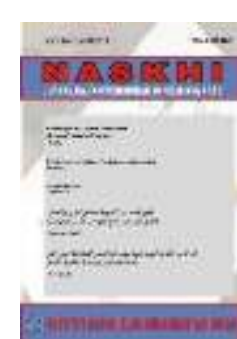

\title{
NASKHI
}

Jurnal Kajian Pendidikan dan Bahasa Arab

Volume 3, No. 2, 2021

ISSN (print) : 2527-5747

ISSN (online) : 2716-3369

Homepage : https://journal.iaimsinjai.ac.id/index.php/naskhi

\section{Penggunaan Bahan Ajar Peta Konsep untuk Meningkatkan Penguasaan Mapel Jurmiyah dalam Proses Pembelajaran Daring}

\author{
Abdur Rauf ${ }^{1}$, Nuril Mufidah ${ }^{2}$ \\ ${ }^{1,2}$ UIN Maulana Malik Ibrahim, Batu, Malang \\ E-mail: abdurrauf001448@gmail.com,Tlp: +6281939184441 \\ DOI: https://doi.org/10.47435/naskhi.v3i2.683
}

This work is licensed under a Creative Commons Attribution-ShareAlike 4.0 International License.

\begin{abstract}
This research aims to improve students' conceptual mastery in Nahwu Jurmiyah subjects by approaching the use of concept maps in the online learning process due to the impossibility of direct face-to-face learning due to the covid-19 outbreak. This study uses qualitative research with a classroom action research approach (CAR). The subjects in this study were students of class VII A \& VII B of the Ministry of Religion MTs Salafiyah Syafi'iyah in 2021. The total population was 70 students with each class containing 35 students. From the data that has been collected, it is concluded that the use of concept maps in Nahwu Jurmiyah subjects in grades VII A \& VII B Ministry of Religion MTs Salafiyah Syafi'tyah in the online learning process can increase students' mastery of concepts to $83 \%$ with an indicator of $80 \%$ of the total population must get a score above 70 . This can be detailed in the first cycle the majority of students were able to absorb mastery of concepts with an average value of 67. While in the second cycle after applying the use of teaching materials with concept maps, the ability of students to absorb understanding of the material increased and increased to an average of 77. And students look more active and can respond better when using teaching materials with concept maps, and students' learning motivation becomes higher.
\end{abstract}

Keywords: Concept Map, Mastery of Nahwu Jurmiyah, Online Learning, Covid 19.

\begin{abstract}
Abstrak
Penelitian yang dilakukan ini bertujuan untuk meningkatkan penguasaan konsep siswa pada mata pelajaran nahwu Jurmiyah dengan pendekatan penggunaan peta konsep dalam proses pembelajaran daring akibat ketidak-mungkinan melakukan pembelajaran tatap muka langsung karena wabah covid19. Penelitian ini menggunakan jenis penelitian kualitatif dengan pendekatan penelitian tindakan kelas (PTK). Subjek dalam penelitian ini adalah siswa kelas VII A \& VII B Depag MTs Salafiyah Syafi'iyah Tahun 2021. Jumlah populasi keseluruhan adalah 70 siswa dengan masing-masing kelas berisi 35 siswa. Dari data yang telah terkumpul diperoleh kesimpulan bahwa penggunaan peta konsep pada mata pelajaran nahwu Jurmiyah di kelas VII A \& VII B Depag MTs Salafiyah Syafi'iyah dalam proses pembelajaran daring dapat meningkatkan penguasaan konsep siswa menjadi $83 \%$ dengan indikator $80 \%$ dari jumlah populasi harus mendapatkan nilai di atas 70. Hal ini dapat dirinci, pada siklus I mayoritas siswa mampu menyerap penguasaan konsep dengan rata-rata nilai 67. Sedangkan dalam siklus ke II setelah diberlakukan penggunaan bahan ajar dengan peta konsep, kemampuan siswa menyerap pemahaman materi menjadi naik dan meningkat menjadi rata-rata 77. Dan siswa terlihat lebih aktif dan dapat merespon dengan lebih baik saat menggunakan bahan ajar dengan peta konsep, serta motivasi belajar siswa menjadi lebih tinggi.
\end{abstract}

Kata Kunci: Peta Konsep, Penguasaan Nahwu Jurmiyah, Pembelajaran Daring, Covid 19. 


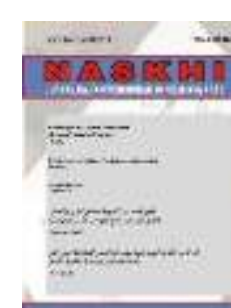

\section{NASKHI}

Jurnal Kajian Pendidikan dan Bahasa Arab

Volume 3, No. 2, 2021

ISSN (print) : 2527-5747

ISSN (online) : 2716-3369

Homepage : https://journal.iaimsinjai.ac.id/index.php/naskhi

\section{Pendahuluan}

Guru memiliki peran yang sangat penting dalam proses pendidikan. Di mana seorang guru diharapkan dapat memberikan kontribusi dalam memberikan kualitas proses pembelajaran yang baik sehingga ilmu yang hendak ditransfer oleh sang guru dapat diserap dengan baik oleh para siswa. Terjadinya serangkaian proses pembelajaran yang baik dan maksimal, tentu tak lepas dari persiapan pembelajaran dari sang guru itu sendiri. Mulai dari perencanaan pembelajaran, pemilihan strategi dan metode, model pembelajaran serta media yang digunakan, sangatlah berpengaruh terhadap kondusifitas kelas saat pembelajaran berlangsung.

Keurgensian ini selayaknya patut sangat dipertimbangkan oleh para guru, lebih-lebih di masa wabah seperti ini. Di mana model pembelajaran saat ini tidak memungkinkan untuk bertatap muka secara langsung. Sehingga model pembelajaran dialihkan kepada model pembelajaran tatap muka dalam jaringan (daring). Adanya covid-19 ini tidak hanya memberikan dampak bagi pendidikan umum, namun juga sangat memberikan dampak terhadap pendidikan pesantren. Oleh karena itu, berbagai inovasi dan kreativitas dalam pembelajaran dicurahkan oleh para guru untuk tetap menunjang pendidikan yang baik selama dalam proses pendidikan daring.

Di mana saat proses pembelajaran daring berlangsung juga menimbulkan persoalan baru. Mulai dari keaktifan siswa yang menurun, sampai target pendidikan yang belum mencapai titik maksimal. Sehingga sangat perlu untuk memberikan gebrakan dan tindakan yang cepat tanggap terhadap masalah yang dialami saat proses pembelajaran daring tersebut. Salah satu gebrakan itu adalah dengan menyediakan bahan ajar yang ramah dan mudah dipahami oleh para siswa. Sehingga pendampingan pembelajaran yang terbatas ruang ini juga dapat dipandu dan dikawal oleh orang tua masing-masing di rumah.

Di antara model bahan ajar yang ramah dan mudah itu adalah bahan ajar yang berbentuk peta konsep. Sehingga para siswa dapat menyerap poin-poin materi pembelajaran yang hendak disampaikan dengan mudah dan sistematis. Lahirnya teori peta konsep dikemukakan pertama kali oleh Tony Buzan di tahun 1974. Menurut Hopper dalam Supriyadi (Supriyadi, ddk, 2021: 62) peta konsep adalah sebuah skema yang dipakai untuk menyusun suatu konsep atau pokok-pokok pikiran secara sistematis dalam bentuk visual. Menurut Buzan (Buzen, 2018:12) dengan penggunaan peta konsep dapat mengoptimalkan potensi pola pikir secara maksimal dalam kinerja otak seseorang. Sehingga proses belajar-mengajar jika diterapkan dengan adanya peta konsep dapat membantu guru dan siswa untuk saling mentransfer dan menerima materi pelajaran dengan mudah dan praktis, serta efisien. Sehingga para siswa dapat melatih kemampuan otaknya secara optimal dan menyerap materi yang disampaikan secara baik dan efektif (Khasanah, 2019: 153).

Berdasarkan paparan di atas, maka penelitian ini bertujuan 1) untuk meningkatkan kemampuan pemahaman/penguasaan siswa terhadap materi pelajaran nahwu Jurmiyah di kelas VII A \& B Depag MTs Salafiyah Syafi'iyah Sukorejo tahun 2021 dalam proses pembelajaran daring. 2) Menaikkan keaktifan siswa. 3) Memacu semangat dan motivasi siswa.

\section{Metode}

Dalam penelitian ini digunakan jenis penelitian kualitatif dengan pendekatan penelitian tindakan kelas (PTK). Subjek dalam penelitian ini adalah siswa kelas VII A \& VII B Depag MTs Salafiyah Syafi'iyah Tahun 2021. Masing-masing kelas berisi 35 siswa. Dengan demikian jumlah populasi keseluruhan adalah 70 siswa. Desain yang dipakai dalam acuan penelitian ini adalah desain model dari Kurt Lewin, yaitu dimulai dari tahap perencanaan, tindakan, pengamatan serta refleksi. Sebagaimana yang disampaikan oleh Wahidmurni \& Ali bahwa hubungan keempat komponen ini disebut sebagai siklus (Wahidmurni \& Ali, 2008: 32).

Untuk melihat adanya perubahan data dari siklus I ke II, maka dibuatlah indikator ketercapaian sebagai berikut. 1) Tingkat motivasi belajar siswa diharapkan menjadi naik pada siklus II setelah menggunakan bahan ajar dengan pendekatan peta konsep. 2) Keaktifan siswa juga lebih tinggi pada siklus II daripada proses pembelajaran sebelum menggunakan bahan ajar dengan pendekatan peta 


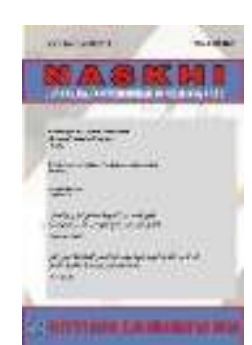

\section{NASKHI}

Jurnal Kajian Pendidikan dan Bahasa Arab

Volume 3, No. 2, 2021

ISSN (print) : 2527-5747

ISSN (online) : 2716-3369

Homepage : https://journal.iaimsinjai.ac.id/index.php/naskhi

konsep. 3) 80\% siswa dari jumlah populasi penelitian diharapkan mampu mendapatkan nilai minimal 70 pada siklus II. Jika seluruh indikator yang disebutkan belum tercapai, maka perlu dilakukan analisis ulang dan pencarian solusi yang tepat dan dilanjutkan pada siklus III.

\section{Hasil dan Pembahasan}

\subsection{Kinerja Siswa Pada Siklus I}

Sebelum diberikan eksperimen berupa penggunaan buku Al-Muyassar Fiy Al-Risalah AlNahwiyah, tingkat motivasi belajar siswa kelas VII A \& VII B Depag cukup kecil. Jika dipersentasekan secara keseluruhan, sekitar $28 \%$ atau 10 siswa dari masing-masing kelas sangat bersemangat. Sebanyak $21 \%$ atau 15 orang dari kedua kelas lumayan bersemangat. Sebanyak $16 \%$ bersikap biasa saja dan 35\% sisanya sama sekali tidak bersemangat.

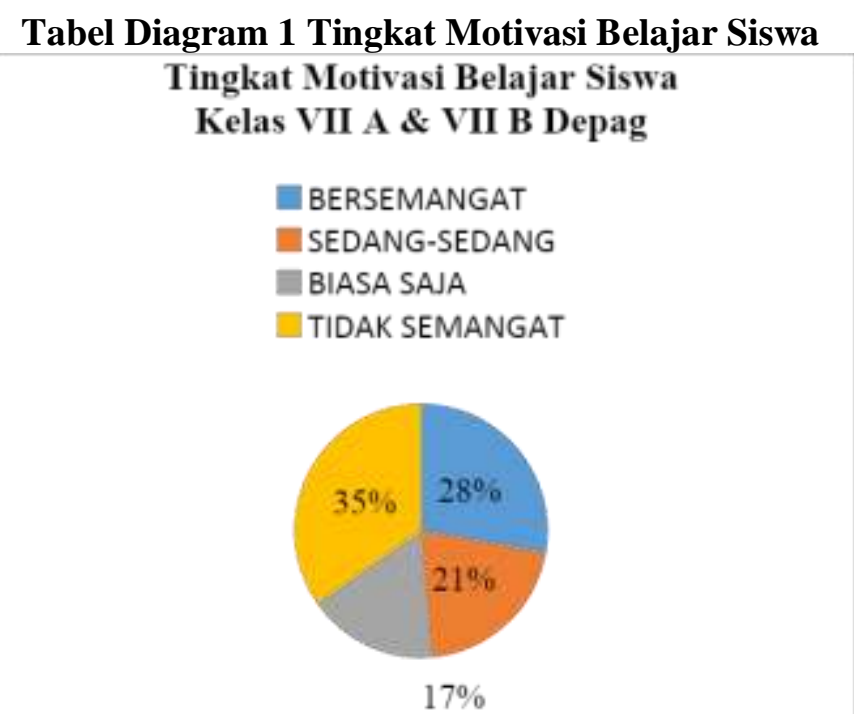

Berdasarkan temuan yang terjadi setelah dilakukan pengamatan di lapangan, maka disebarlah angket untuk melihat dan mengevaluasi minimnya tingkat motivasi belajar siswa tersebut. Lihatlah tabel hasil angket di bawah ini!

Tabel Grafik 1 Faktor Rendahnya Motivasi Belajar Faktor Rendahnya Motivasi Belajar

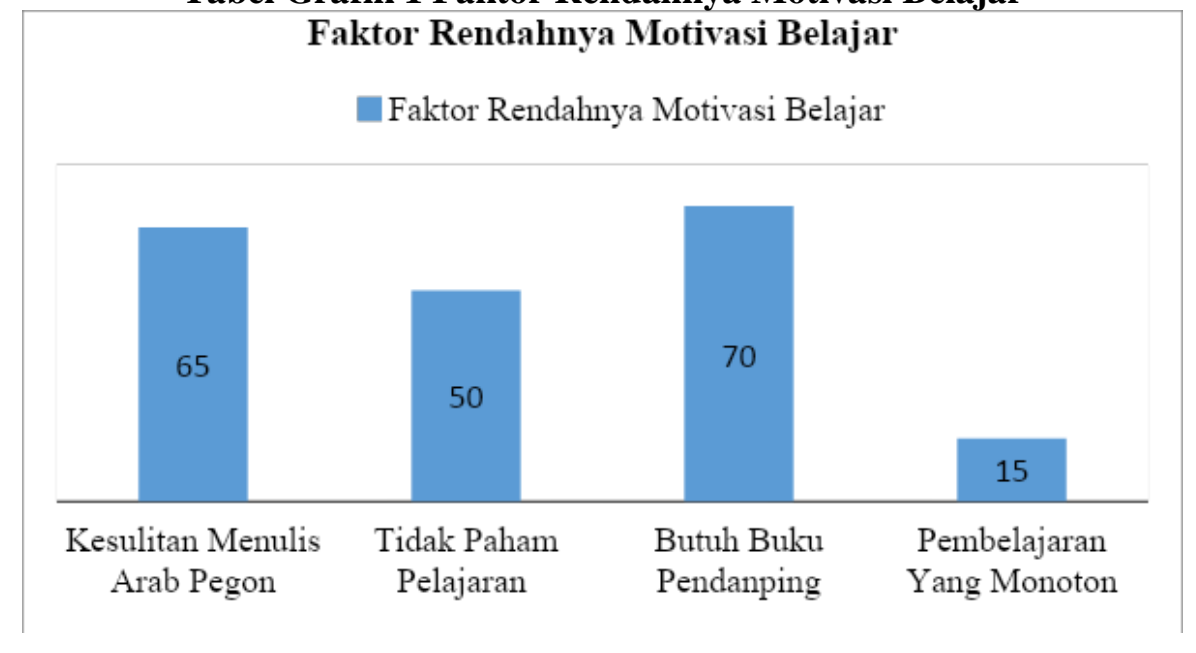




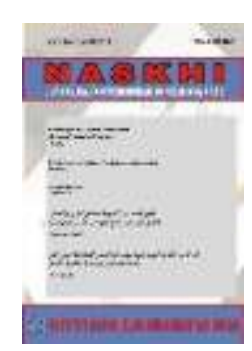

\section{NASKHI}

\section{Jurnal Kajian Pendidikan dan Bahasa Arab}

Volume 3, No. 2, 2021

ISSN (print) : 2527-5747

ISSN (online) : 2716-3369

Homepage : https://journal.iaimsinjai.ac.id/index.php/naskhi

Dari jumlah populasi yang diteliti sebanyak 70 siswa, ada beberapa faktor yang mempengaruhi rendahnya minat dan motivasi siswa dalam proses belajar. Faktor pertama, hampir seluruhnya menyatakan bahwa mereka kesulitan dalam mengartikan kitab ke dalam bahasa Indonesia dengan arab pegon (bahasa Indonesia yang ditulis dengan huruf Arab). Hal ini bisa terjadi karena 2 faktor. Pertama, sebagian besar dari mereka mengungkapkan bahwa belum pernah sama sekali menulis arab pegon. Kedua, sebagian dari mereka mengungkapkan belum terbiasa menulis arab pegon. Faktor kedua yang mempengaruhi rendahnya minat dan motivasi siswa dalam belajar adalah tidak paham materi pelajaran. Hal ini juga ada beberapa faktor. Pertama, ada yang memang tidak paham secara murni. Kedua, siswa tidak mencatat keterangan guru saat dituliskan di papan tulis/slide. Ketiga, siswa mencatat keterangan guru yang ditulis di papan/slide namun tidak sampai selesai karena waktu pembelajaran telah usai dan pergantian jam pelajaran.

Selanjutnya, faktor ketiga yang mempengaruhi rendahnya minat dan motivasi siswa dalam belajar adalah tidak tersedianya buku pendamping belajar yang mudah dipelajari dengan bahasa seharihari. Baik dapat dipelajari secara kolektif di kelas ataupun dipelajari secara mandiri di luar kelas. Sebagaimana yang disampaikan Daryanto (Daryanto, 2014: 171) dalam Susilawati, dkk (Susilawati, dkk, 2020: 63) bahwa adanya bahan ajar bertujuan untuk memenuhi kebutuhan peserta didik sesuai kapasitasnya. Dengan tidak adanya ketersediaan buku pendamping belajar ini, maka bisa menimbulkan beberapa faktor penghambat. Pertama, siswa tidak dapat buku acuan untuk dipelajari sebelum pelajaran dimulai. Kedua, mereka tidak bisa mengulang kembali pelajaran yang telah disampaikan guru karena keterbatasan bahan bacaan. Ketiga, proses pembelajaran menjadi tidak terkontrol dan terarah. Faktor keempat yang mempengaruhi rendahnya minat dan motivasi siswa dalam belajar adalah pelajaran yang monoton (Sururuddin \& Nirmala, 2018: 61). Sehingga para siswa merasa jenuh dan kehilangan fokus dalam belajar. Kejenuhan para siswa ini juga sangatlah patut diperhatikan oleh guru untuk membangun kondisi kelas yang nyaman dan kondusif, lebih-lebih dalam kondisi belajar daring.

\subsection{Ketuntasan dan Penguasaan Konsep Pada Siklus I}

Pada siklus I, sebelum diberikan pembelajaran menggunakan peta konsep, dilakukan uji coba menggunakan soal-soal untuk melihat keterserapan siswa dalam memahami materi yang diajarkan saat proses daring berlangsung.

Tabel 1 Hasil Nilai Ketercapaian Siklus I

\begin{tabular}{|l|c|}
\hline \multicolumn{1}{|c|}{ Kategori } & $\begin{array}{c}\text { Hasil Belajar Siklus } \\
\text { I }\end{array}$ \\
\hline Nilai Tertinggi & 80 \\
\hline Nilai Terendah & 50 \\
\hline Nilai Rata-Rata & 67 \\
\hline Rentang nilai & 30 \\
\hline Tuntas KKM & 51 \\
\hline Tidak tuntas KKM & 19 \\
\hline
\end{tabular}

Setelah dilakukan tes pada siklus I, dijumpai bahwa peringkat nilai tertinggi pada siklus pertama ini adalah 80 dan nilai terkecil adalah 50. Di mana nilai rata-rata pada populasi ini adalah 67. Sedangkan rentang nilai pada siklus ini adalah 30. Jumlah ketuntasan siswa dengan ketetapan nilai KKM 60 diperoleh sebanyak 51 siswa, sedangkan 19 siswa sisanya perlu dilakukan remedi. Data-data nilai tersebut dapat dirinci sebagaimana diagram di bawah ini. 


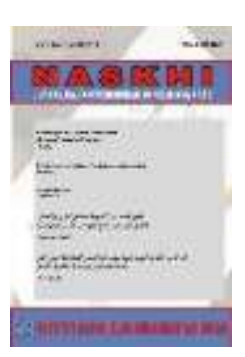

\section{NASKHI}

Jurnal Kajian Pendidikan dan Bahasa Arab

Volume 3, No. 2, 2021

ISSN (print) : 2527-5747

ISSN (online) : 2716-3369

Homepage : https://journal.iaimsinjai.ac.id/index.php/naskhi

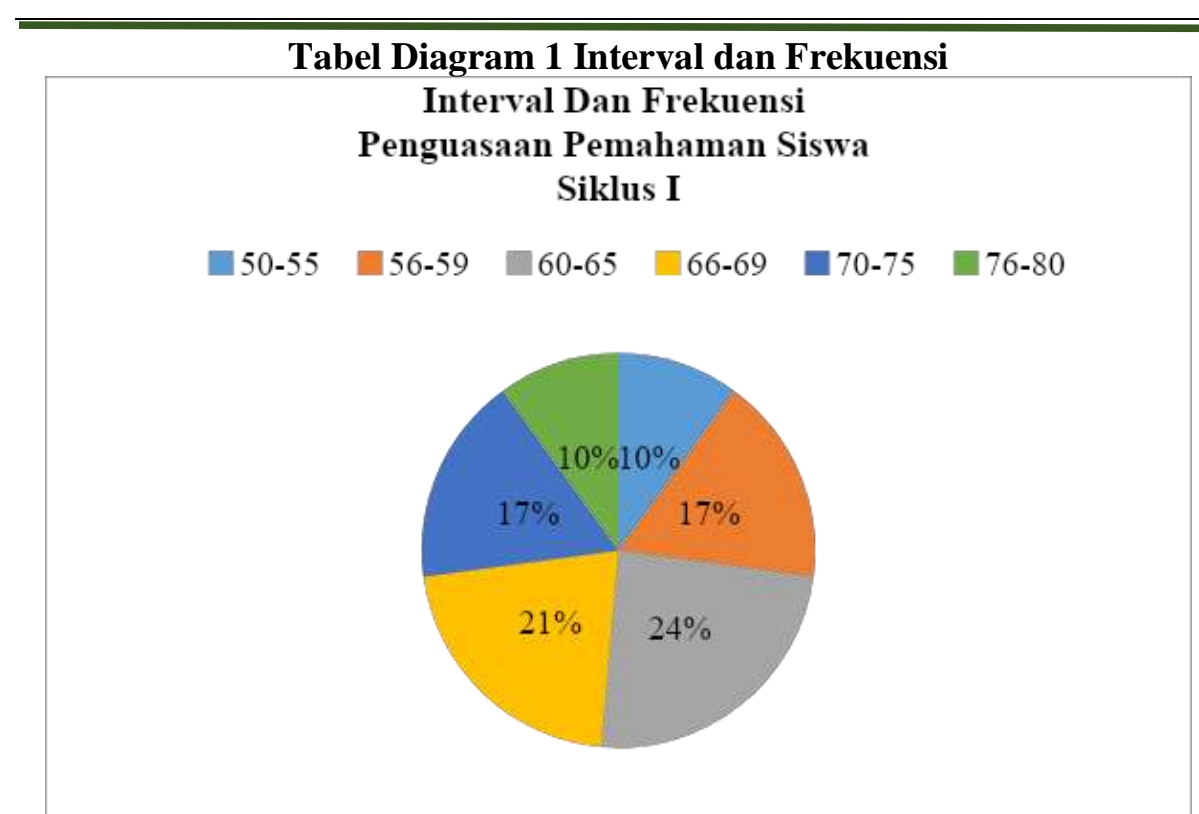

Sebanyak $10 \%$ atau 7 orang siswa mendapatkan nilai dari kisaran 50 sampai 55. 17\% atau 12 orang siswa mendapatkan nilai kisaran 56 sampai 59. 17 Siswa atau 24\% mendapatkan nilai dari kisaran 60-65. 22\% atau 15 siswa mendapatkan nilai dari kisaran 66-69. $17 \%$ atau 12 siswa mendapatkan nilai dari kisaran 70-75. Dan 10\% sisanya atau 7 orang siswa mendapatkan nilai dari kisaran 76 sampai 80.

Atas dasar paparan sebagaimana di atas, menunjukkan bahwa keterserapan pemahaman siswa terhadap materi yang disampaikan masih kecil. Meskipun secara data kriteria ketuntasan minimal (KKM) banyak siswa yang sudah dinyatakan tuntas. Oleh karena itu, butuh dilaksanakan upaya dalam meningkatkan keterserapan materi yang diajarkan kepada siswa.

\subsection{Pengemasan Materi Jurmiyah dalam Bentuk Peta Konsep}

Kitab Jurmiyah sudah bukan hal yang baru di dunia pesantren. Kitab ini dikarang pada abad 7 Hijriyah/13 Masehi oleh Abu Abdillah Muhammad bin Daud al-Shonhaji atau yang lebih dikenal dengan sebutan Ibnu Ajurrum (Al-Shonhaji, tt: 1).

Di pesantren kitab ini sudah menjadi standar turun-temurun bagi setiap siswa yang hendak mempelajari kaidah nahwu dasar. Khususnya di pondok pesantren Salafiyah Syafi'iyah. Bahkan, semudah-mudahnya kitab Jurmiyah tetaplah asing dan terasa sulit bagi santri baru yang dari awal tidak mengenal dunia kitab kuning. Lebih-lebih bahasa yang digunakan di dalam kitab Jurmiyah masih menggunakan bahasa Arab. Permasalahan inilah yang menjadi salah satu pendorong terhadap terjadinya penghambat/kendala bagi santri baru yang hendak mempelajari ilmu nahwu dasar. Khususnya di lembaga MTs Salafiyah Syafi'iyah kelas VII A dan B Depag.

Oleh karena itu, dibutuhkan upaya kreatif untuk mengadakan bahan belajar penunjang bagi siswa baru yang hendak mempelajari kitab Jurmiyah. Lebih-lebih dalam proses pembelajaran daring pada saat wabah corona seperti saat ini.

Salah satu upaya itu adalah mengemas kitab Jurmiyah ke dalam bentuk peta konsep menggunakan bahasa sehari-hari yang mudah dipahami, yaitu bahasa Indonesia. Menurut Swadarma dalam Widia (Widia, dkk, 2020: 468) pembelajaran yang menggunakan pendekatan peta konsep dapat memberikan banyak manfaat yang berhubungan dengan penguasaan konsep.

Aris Shoimin (Shoimin, 2014: 105) berpendapat bahwa penggunaan peta konsep adalah suatu teknik untuk mengoptimalkan kemampuan otak dengan penggunaan media visual dan grafis sehingga membentuk kesan yang kuat di dalam otak.

Pengemasan kitab Jurmiyah ke dalam peta konsep ini mengikuti sub-sub bab sebagaimana kitab aslinya (Kholil, 2019: 84). Mulai dari macam-macam kalimat, isim-isim yang dibaca rofa', isimisim yang dibaca nashob, dan ditutup dengan pembahasan isim-isim yang dibaca khofad/jer. 


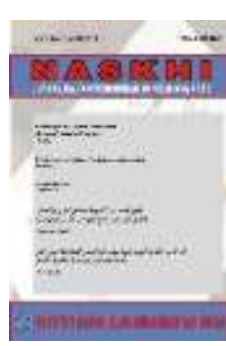

\section{NASKHI}

Jurnal Kajian Pendidikan dan Bahasa Arab

Volume 3, No. 2, 2021

ISSN (print) : 2527-5747

ISSN (online) : 2716-3369

Homepage : https://journal.iaimsinjai.ac.id/index.php/naskhi

Lihatlah contoh penggunaan peta konsep pada gambar di bawah ini!
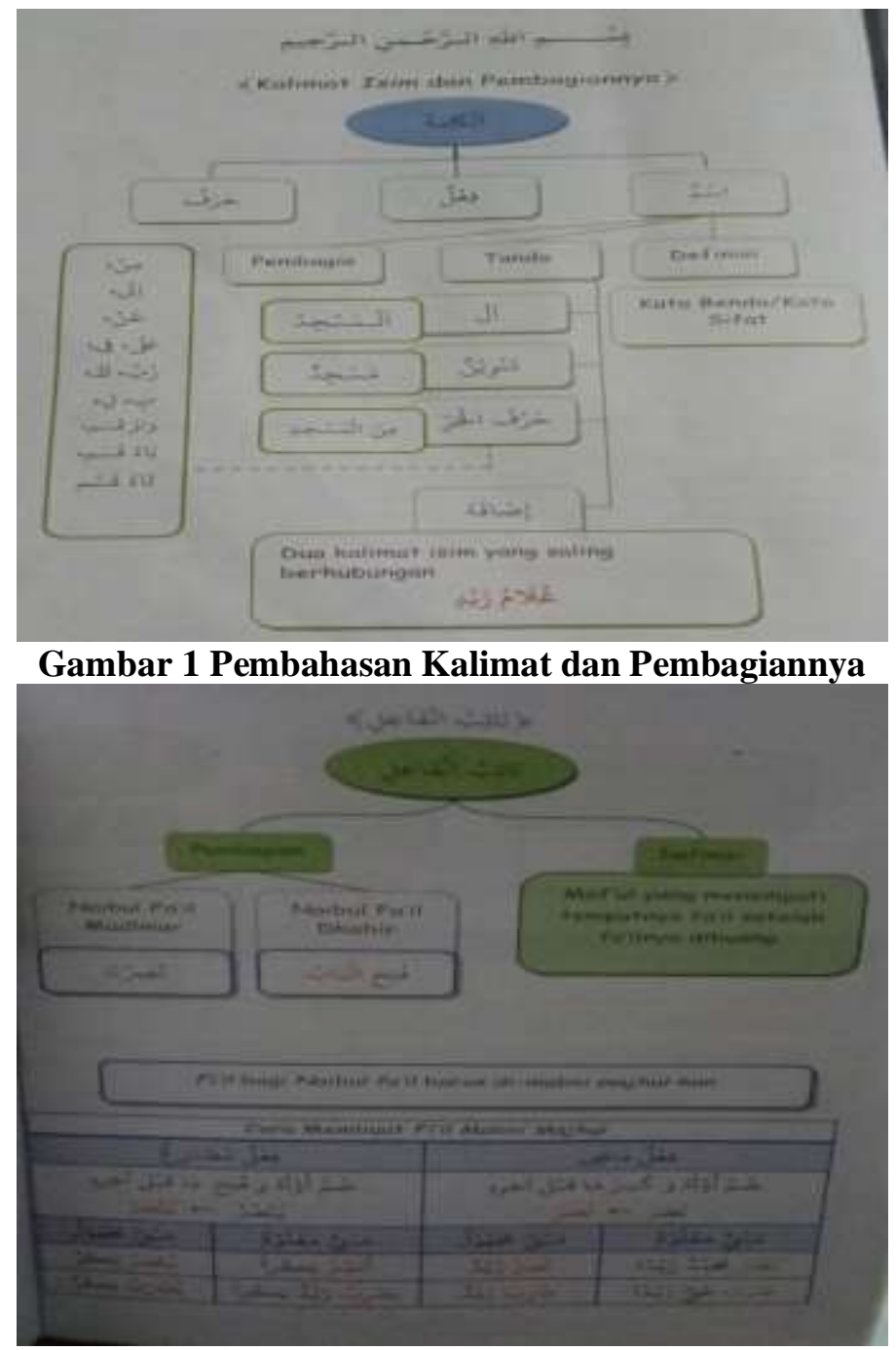

Gambar 2 Pembahasan Isim-Isim yang Dibaca Rofa'(Naibul Fa'il)

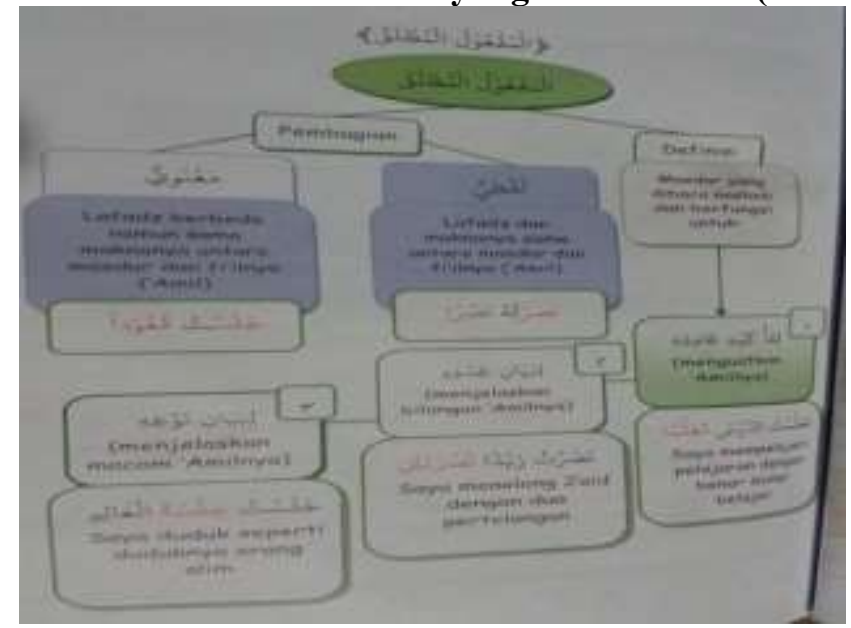

Gambar 3 Pembahasan Isim-Isim yang Dibaca Nashob (Maf'ul Mutlaq) 


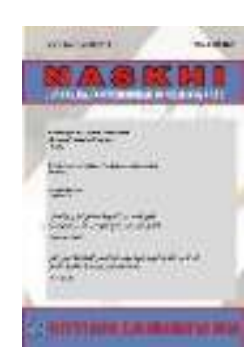

\section{NASKHI}

Jurnal Kajian Pendidikan dan Bahasa Arab

Volume 3, No. 2, 2021

ISSN (print) : 2527-5747

ISSN (online) : 2716-3369

Homepage : https://journal.iaimsinjai.ac.id/index.php/naskhi

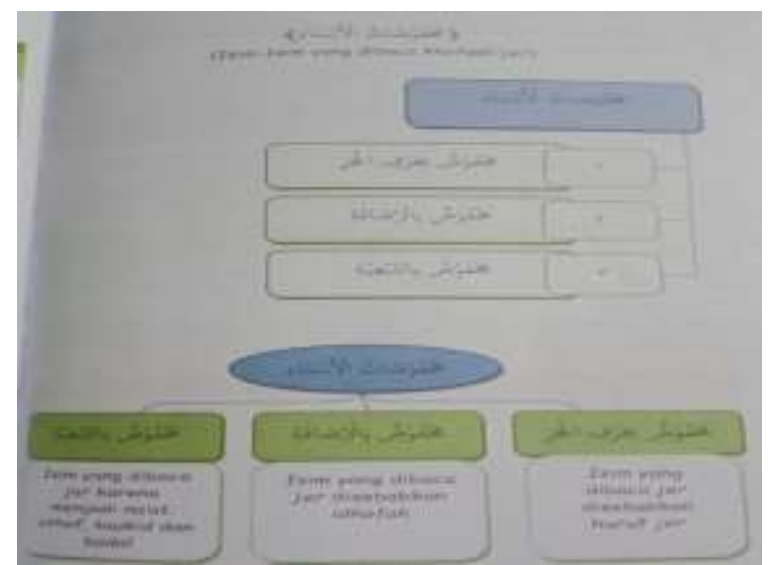

Gambar 4 Pembahasan Isim-Isim yang Dibaca Jer

Dengan adanya penggunaan peta konsep dalam suatu bahan ajar sebagaimana contoh pada gambar di atas, dapat memudahkan siswa untuk belajar dan memahami isi pelajaran yang hendak disampaikan baik secara kolektif ataupun secara mandiri.

Di samping itu, adanya penggunaan peta konsep dapat menarik minat dan motivasi siswa untuk semakin giat belajar. Karena poin-poin pembelajaran sudah dikemas secara sistematis, mudah, dan menarik karena dilengkapi dengan penggunaan warna yang full colour.

Selain konten isi yang harus memadai, pemilihan diksi yang baik serta warna yang menarik, hal yang tidak kalah penting dalam buku sebuah bahan ajar adalah adanya evaluasi. Sebagaimana yang dikemukakan oleh M. Ngalim Purwanto (Purwanto, 2005: 26) bahwa setiap guru wajib memberikan suatu evaluasi terhadap materi yang telah disampaikan.

Hal senada juga disampaikan oleh M. Chabib Thoha (Thoha, 1990:17) bahwa evaluasi adalah sebuah kegiatan yang dirancang untuk melihat/mengukur keadaan suatu objek dengan bantuan instrumen di mana kelak hasilnya dapat diolah untuk mengambil dasar kesimpulan.

Di antara instrumen evaluasi yang ada dalam buku ini adalah soal-soal yang didesain per subsub bab dengan variasi 3 pola soal. 1) Pola soal berbentuk pilihan ganda. 2) Pola soal berbentuk tabel essay. 3) dan pola soal berbentuk teka-teki silang sebagaimana yang dilaksanakan oleh Wirani (Wirani, 2018:165).

Adanya evaluasi berbentuk pilihan ganda dapat merangsang pikiran siswa karena terbantu dengan adanya pilihan-pilihan jawaban. Sehingga para siswa dapat mengingat dan menyerap suatu konsep materi dengan mudah.

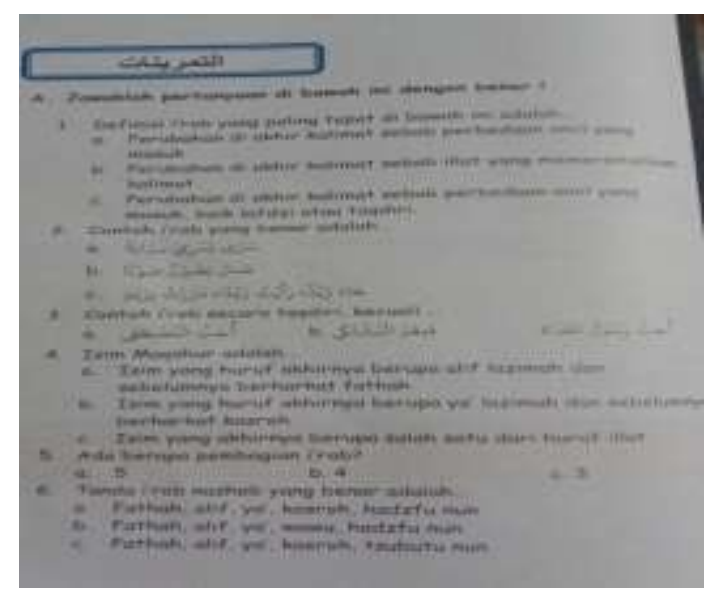

Gambar 5 Contoh Evaluasi Pilihan Ganda 


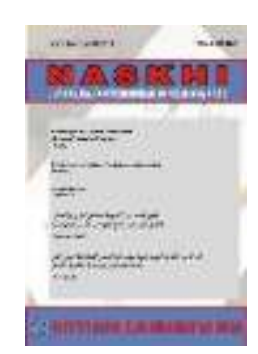

\section{NASKHI}

\section{Jurnal Kajian Pendidikan dan Bahasa Arab}

Volume 3, No. 2, 2021

ISSN (print) : 2527-5747

ISSN (online) : 2716-3369

Homepage : https://journal.iaimsinjai.ac.id/index.php/naskhi

Sedangkan adanya evaluasi berbentuk essay dapat memberikan siswa keterampilan menulis dan mengekspresikan pemahaman yang telah diserap serta mengasah ketelitian (Siswanto, 2006: 56). Hal ini sangatlah bagus untuk melatih saraf motorik peserta didik dan melatih siswa untuk menulis huruf-huruf arab.

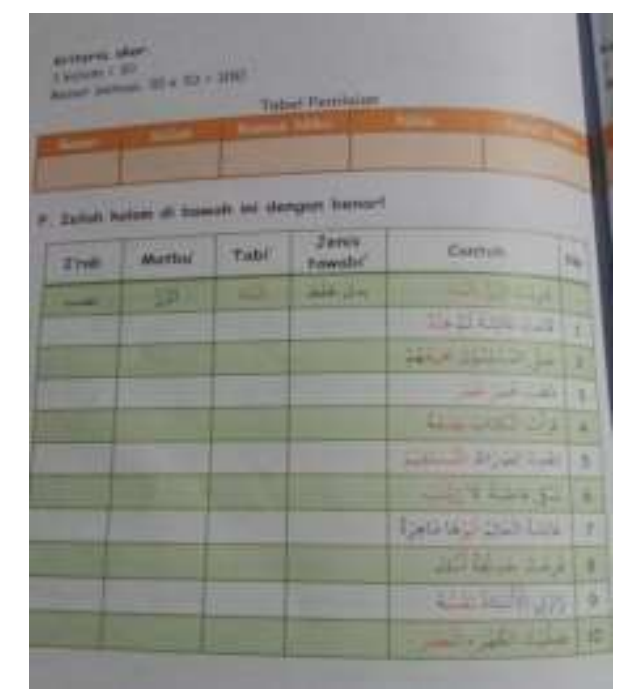

\section{Gambar 6 Contoh Evaluasi Tabel Essay}

Menurut Rani Fathonah, dkk (S, Rani Fathonah., dkk, 2013: 70) teka-teki silang adalah sebuah permainan menuliskan huruf-huruf pada kotak-kotak kosong sehingga jawaban yang diisi membentuk sebuah kata baik secara vertikal maupun horizontal. Adanya evaluasi berbentuk teka-teki silang ini memiliki daya tarik yang kuat untuk melatih siswa membaca (Kadek, 2017: 2). Sehingga diharapkan konsep-konsep Jurmiyah dalam buku ini lebih bisa diserap dengan adanya rangsangan melalui permainan teka-teki silang ini. Sebagaimana yang dikemukakan Rantika, teka-teki silang dapat dijadikan salah satu media yang sangat cocok untuk melatih kemampuan siswa dalam membaca, menghafal dan menulis (Rantika, 2015: 181).

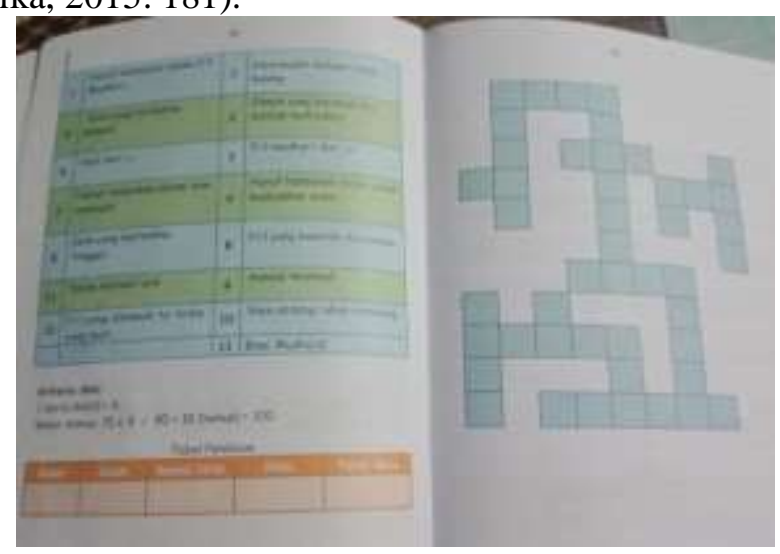

Gambar 6 Contoh Evaluasi Teka-Teki Silang 


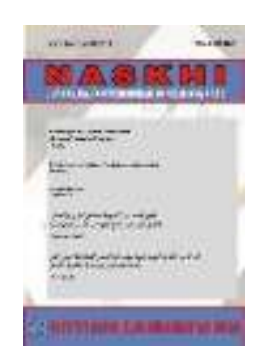

\title{
NASKHI
}

Jurnal Kajian Pendidikan dan Bahasa Arab

Volume 3, No. 2, 2021

ISSN (print) : 2527-5747

ISSN (online) : 2716-3369

Homepage : https://journal.iaimsinjai.ac.id/index.php/naskhi

\subsection{Ketuntasan dan Penguasaan Konsep Pada Siklus II}

Setelah diberlakukan penggunaan bahan ajar melalui pendekatan peta konsep dan dilakukan evaluasi. Dapat diperoleh hasil data nilai tertinggi yang diperoleh siswa berada di angka 98 dan nilai terendah 57.

Tabel 1 Hasil Nilai Ketercapaian Siklus II

\begin{tabular}{|l|c|}
\hline Kategori & Hasil Belajar Siklus II \\
\hline Nilai Tertinggi & 98 \\
\hline Nilai Terendah & 57 \\
\hline Nilai Rata-Rata & 77 \\
\hline Rentang nilai & 41 \\
\hline Tuntas KKM & 63 \\
\hline Tidak tuntas KKM & 7 \\
\hline
\end{tabular}

Tabel Diagram 1 Interval dan Frekuensi

\author{
Interval Dan Frekuensi \\ Penguasaan Pemahaman Siswa \\ Siklus II
}

$\square 0-59 \square 60-69 \square 70-79 \square 80-89 \square 90-100$

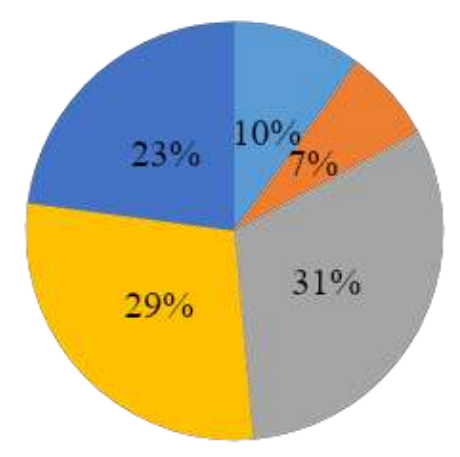

Data interval dan frekuensi di atas dapat dirinci $10 \%$ atau sebanyak 7 siswa dari jumlah populasi yang diteliti masih tertinggal. 5 siswa atau $7 \%$ dari dari jumlah populasi yang diteliti mencukupi kriteria ketuntasan minimal (KKM). $31 \%$ atau 22 siswa dari jumlah populasi yang diteliti mengalami perubahan yang cukup menggembirakan, yakni hasil evaluasi penguasaan konsep yang mereka serap jika dinilai kisaran 70 sampai 79. Dan 52\% sisanya sangat memuaskan dengan kisaran nilai 80 sampai 100 . Dengan demikian, nilai rata-rata pada siklus II ini meningkat menjadi 77 dari rata-rata nilai sebelumnya 67 pada siklus ke I.

Dalam siklus ke II ini, respon dan keaktifan siswa juga mengalami perubahan yang menggembirakan. Dari sebelumnya yang hanya lebih dominan oleh guru, kini siswa terlihat lebih responsif sehingga suasana kelas daring menjadi lebih hidup. Sebagaimana yang disampaikan Spronken bahwa siswa akan timbul rasa keingintahuan dan gairahnya terhadap sesuatu yang tidak sama daripada sebelumnya (Spronken-Smith, 2008: 5). Hal ini juga diperkuat oleh Nana Sudjana, ketidak-aktifan siswa tidak semata-mata dilatarbelakangi oleh ketidakmampuan siswa itu sendiri. Melainkan juga ada faktor lain, semisal dari bahan ajar yang digunakan dan proses pembelajaran itu sendiri (Sujana, 2005: $111)$. 


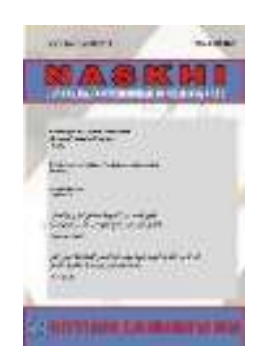

\section{NASKHI}

\section{Jurnal Kajian Pendidikan dan Bahasa Arab}

Volume 3, No. 2, 2021

ISSN (print) : 2527-5747

ISSN (online) : 2716-3369

Homepage : https://journal.iaimsinjai.ac.id/index.php/naskhi

Demikian pun tingkat motivasi belajar siswa menjadi lebih bergairah baik saat proses pembelajaran berlangsung, atau belajar mandiri di rumah masing-masing dengan didampingi orang tua. Sebagaimana yang disampaikan Ibrahim bahwa ketika keingintahuan siswa itu timbul maka akan mendorong motivasi di dalam jiwa siswa itu sendiri (Ibrahim, 2011, 13). Lihatlah grafik perbandingan siklus I dan II di bawah ini!

Tabel Grafik 1 Perbandingan Perubahan dari Siklus I ke Siklus II

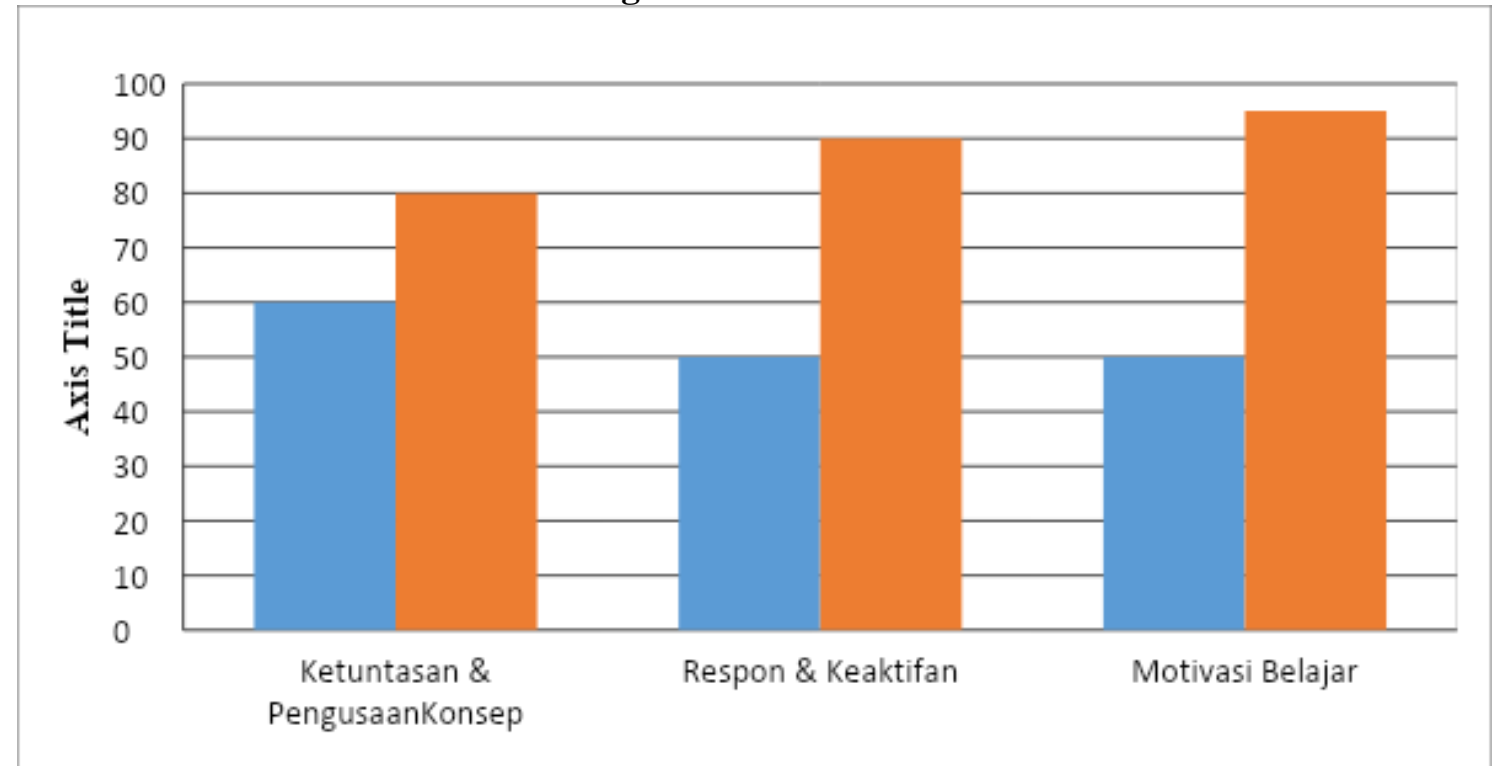

\section{Simpulan}

Keberhasilan program pembelajaran tidak hanya ditentukan oleh satu dua faktor saja. Melainkan ada banyak faktor penunjag. Di antaranya faktor guru, cara mengajar, bahan ajar yang dipakai, sarana pra-sarana serta media pembelajaran yang digunakan (Ihsan, dkk, 2007, 219).

Dari paparan yang disampaikan di atas, dapat ditarik kesimpulan bahwa dalam penelitian ini penggunaan peta konsep dalam upaya peningkatan penguasaan konsep siswa pada mata pelajaran nahwu Jurmiyah kelas VII A \& B Depag MTs Salafiyah Syafi' iyah mengalami peningkatan yang cukup signifikan. Sebagaimana indikator yang telah disebutkan di atas bahwa 83\% siswa dari 70 siswa yang diteliti mampu menyerap materi pelajaran dengan kemampuan di atas 70. Sementara sebelum adanya penggunaan peta konsep, kemampuan siswa dalam menyerap materi hanyalah sekitar $60 \%$ saja. Dari segi keaktifan dan motivasi siswa juga mengalami perubahan yang signifikan setelah adanya proses pembelajaran menggunakan peta konsep.

Setelah adanya penelitian ini, diharapkan dapat memberikan kontribusi dan menjadi salah satu solusi alternatif dalam menunjang proses pembelajaran yang baik khususnya dalam proses belajarmengajar daring selama masa pandemi covid-19 ini. Meski penggunaan peta konsep dirasa mampu memberikan peningkatan penguasaan konsep pada mata pelajaran nahwu Jurmiyah, tidak menutup kemungkinan terjadi hasil yang berbeda pada mata pelajaran yang lain dan pada kondisi yang berbeda pula. 


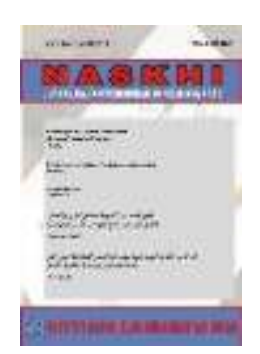

\section{NASKHI}

\section{Jurnal Kajian Pendidikan dan Bahasa Arab}

Volume 3, No. 2, 2021

ISSN (print) : 2527-5747

ISSN (online) : 2716-3369

Homepage : https://journal.iaimsinjai.ac.id/index.php/naskhi

\section{Daftar Pustaka}

Al-Shonhaji, Abu Abdillah Muhammad bin Daud. Al-Ajurrumiyah. Surabaya: Alhidayah.

Buzan, Toni. (2010). Buku Pintar Mind Map. Jakarta: Gramedia Pustaka (Alih Bahasa: Susi Purnoko).

Daryanto. (2014). Pembelajaran Tematik, Terpadu, Terintegrasi (Kurikulum 2013). Yogyakarta: Gava Media.

Ibrahim, M. (2011). Assessment Berkelanjutan, Konsep Dasar Tahapan Pengembangan Dan Contoh. Surabaya: Unesa University Press.

Ihsan, Hamdani, dkk. (2007). Filsafat Pendidikan Islam. Bandung: Pustaka Setia, cet. 3.

Kadek, Wirahyuni. (2017). Meningkatkan Minat Baca Melalui Permainan Teka-Teki Silang Dan Balsem Plang. Acarya Pustaka Jurnal Ilmiah Perpustakaan Dan Informasi, 3(1), 1-11. doi: http://dx.doi.org/10.23887/ap.v3i1.12731

Khasanah, Khuswatun. (2019). Peta Konsep Sebagai Strategi Meningkatkan Hasil Belajar Siswa Sekolah Dasar. E-Jurnal Edu Trained, 3(2), 152-164. Diakses dari https://bdksemarang.ejournal.id/Ed/article/download/8/3/

Kholil, Muhammad, dkk. (2019). Almuyassar Fiy Arrisalah Annahwiyah. Situbondo: Tanwirul Afkar.

Purwanto, M. Ngalim. (2005). Ilmu Pendidikan Teoritis dan Praktis. Bandung: PT Remaja Rosdakarya, cet. 1 .

Rantika. (2015). Penggunaan Media Teka-Teki Silang Dala Meingkatkan Hasil Belajar Siswa Kelas II Pada Pembelajaran Bahasa Arab Di Adrasah Ibtidaiyah Nurul Iman Pengabuan Kabupaten Pali. E-Jurnal Ilmiah PGMI, I(1), 181-194. Diakses dari http://jurnal.radenfatah.ac.id/index.php/jip/article/view/522

S, Rani Fathonah., Sugiharto, Suryadi Budi Utomo. (2013). Studi Komparasi Penggunaan Media TekaTeki Silang (TTS) Dengan Kartu Pada Pembelajaran Kimia Melalui Pendekatan Contextual Teaching And Learning (CTL) Terhadap Prestasi Belajar Siswa Pada Materi Zat Adiktif Dan Psikotropika Kelas VIII SMP N 2 Ngadirojo, Wonogiri Tahun Pelajaran 2011/2012. E-Jurnal Pendidikan Kimia (JPK), 2(3), 68-76. Diakses dari https://jurnal.fkip.uns.ac.id/index.php/kimia/article/view/1238/1768

Shoimin, Aris. (2014). 68 Model Pembelajaran Inovatif Dalam Kurikulum 2013. Yogyakarta: Ar-ruzz Media.

Siswanto. (2006). Penggunaan Tes Essay Dalam Evaluasi Pembelajaran. E-Jurnal Pendidikan Akuntansi Indonesia, 5(1), 55-61. Diakses dari https://journal.uny.ac.id/index.php/jpakun/article/view/864

Spronken-Smith, R. (2008). Experiencing the Process of Knowledge Creation: The Nature and Use of Inquiry-Based Learning in Higher Education. E-Journal of Research. New Zealand: University of Otago, 1-17. Diakses dari http://docplayer.net/17093259-Experiencing-the-process-ofknowledge-creation-the-nature-and-use-of-inquiry-based-learning-in-higher-education.html

Sudjana, Nana. (2005). Dasar-Dasar Proses Belajar Mengajar. Bandung: Sinar Baru, cet. 5.

Supriyadi, Wulan Ayu Damayanti, Nukbatul Bidayati Haka. (2021). Model DILEMMA: Pembelajaran Berpikir Kreatif Melalui Penemuan dan Pemetaan Pemikiran. Jurnal Pendidikan Biologi, 10 (1), 60-70. doi: https://doi.org/10.24114/jpb.v10i1.22643.

Sururuddin, Muhammad., Nirmala Prihatini. (2018). Analisis Berbagai Faktor Penyebab Rendahnya Motivasi Belajar Siswa Kelas IV SDN 3 Tebaban. Jurnal Didika: Wahana Ilmiah Pendidikan Dasar, 4(1), 56-61. doi https://doi.org/10.29408/didika.v4i1.1198

Susilawati, Fitriah., Gunarhadi, Hartono. (2020). Pentingnya Pengembangan Bahan Ajar Tematik Dalam Peningkatan Karakter Peduli Lingkungan Siswa. Eduhumaniora Jurnal Pendidikan Dasar, 12(1), 62-68. doi: https://doi.org/10.17509/eh.v12i1.15068

Thoha, M. Chabib. (1990). Teknik Evaluasi Pendidikan. Jakarta: PT. Raja Grafindo, cet. 1.

Wahid Murni \& Nur Ali. (2008). Penelitian Tindakan Kelas. Malang: UM Press. 
Volume 3, No. 2, 2021

ISSN (print) : 2527-5747

ISSN (online) : 2716-3369

Homepage : https://journal.iaimsinjai.ac.id/index.php/naskhi

Widia, Fitria Sarnita, Fathurrahmaniah, Jessy Parmawati Atmaja. (2020). Penggunaan Strategi Mind Mapping Untuk Meningkatkan Penguasaan Konsep Siswa. E-Jurnal Ilmiah Mandala Education, 6(2), 467-473. $\quad$ Diakses dari http://ejournal.mandalanursa.org/index.php/JIME/article/view/1459

Wirani, Nency Dila. (2018). Pengembangan Alat Evaluasi Berbantu Media Teka-Teki Silang Pada Mata Pelajaran Marketing Kompetensi Dasar Menerapkan Promosi Produk Di Smk Ketintang. EJurnal Pendidikan Tata Niaga, 6(4), 165-174. Diakses dari https://ejournal.unesa.ac.id/index.php/jptn/article/view/25598 